\section{Southern, Edwin Mellor}

\author{
A. M. Gressner ${ }^{1}$ und O. A. Gressner ${ }^{2}$ \\ ${ }^{1}$ Labor Dr. Wisplinghoff Berlin, Berlin, Deutschland \\ ${ }^{2}$ Labor Dr. Wisplinghoff Köln, Köln, Deutschland
}

Lebensdaten Englischer Chemiker und Molekularbiologe, geboren am 7. Juni 1938 in Burnley, Lancashire, UK.

Verdienste Nach dem Studium der Chemie an der University of Manchester (1958) und Promotion an der University of Glasgow (1962) arbeitet Southern als Molekularbiologe am Medical Research Council (MRC) der University of Edinburgh, wo er sich methodisch mit der DNA-Sequenzanalyse beschäftigte. Dort entwickelte er auch die nach ihm benannte
Methode des „Southern Blots“ zum Nachweis spezifischer DNA-Sequenzen, die er 1975 im Journal of Molecular Biology publizierte ( $\triangleright$ Southern-Blot-Analyse). Weitere Projekte in seiner Zeit als Direktor des Institutes of Biochemistry an der University of Oxford waren auf die Kartierung des humanen Genoms und auf die Entwicklung von DNA-Chips gerichtet.

\section{Literatur}

Harding A (2005) Sir Edwin Southern: scientist as problem solver. Lancet 366:1919

Southern EM (1975) Detection of specific sequences among DNA fragments separated by gel electrophoresis. J Mol Biol 98(3):503-517 